\title{
New Perspectives Related to the Bioluminescent System in Dinoflagellates
}

\author{
Created by: Carlos Fajardo
}

Version received: 24 March 2020

check for

updates

\begin{abstract}
The mechanisms underlying the bioluminescent phenomenon have been well characterized in dinoflagellates; however, there are still some aspects that remain an enigma. Such is the case of the presence and diversity of the luciferin-binding protein (LBP), as well as the synthesis process of luciferin. We carry out a review of the literature in relation to the molecular players responsible for bioluminescence in dinoflagellates, with particular interest in P. lunula.
\end{abstract}

Dinoflagellates are the most important eukaryotic protists that produce light $[\underline{1}][\underline{2}]$. This singularity has inspired not only literature and art, but also an intensive scientific dissection [3]][4][]]. Pyrocystis has been a main model genus for a long time in the study of bioluminescence in dinoflagellates [] $][$ ] $][8][\underline{9}][\underline{10}]$; as well as in the development of some biotechnological applications associated with its bioluminescence

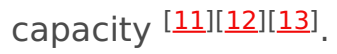

All dinoflagellates belong to the Dinophyceae group and have been unchallengeably placed using extensive molecular phylogenetic data within the Alveolata group, being closely related to the Apicomplexa group, which includes many parasitic species [14] . Pyrocystis (Dinophyceae) spends a large

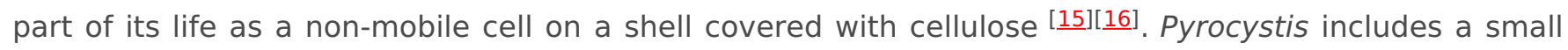
number of marine species that have a cosmopolitan distribution [1]. The life cycles of $P$. lunula, as in other species of this genus, it is characterized by a normal asexual reproduction linked to simple alternations of coccoid cells and morphologically different transitory reproductive stages. There are different reproductive bodies depending of the species. In the case of $P$. Iunula, the reproductive bodies are athecate-uniflagellate planospores. In $P$. noctiluca and $P$. fusiforrnis are athecate aplanospores. For $P$. lanceolate are athecate-biflagellate, and in $P$. acuta are thecate-biflagellate ${ }^{[18}$ ]. Furthermore, evidence of sexual reproduction has been reported in $P$. lunula $[\underline{19]}$. The $P$. lunula lifestyle is also characterized by the execution of vertical migrations in relation to the circadian rhythm [20].

The bioluminescent light is generated by a chemical reaction. Although the process is not the same in all the bioluminescent organisms, most of them share the same base reaction; where the LCF enzyme reacts with the luciferin (substrate) in presence of oxygen and produces an oxyluciferin that emits a photon while it decays from a high to a low energy state. There are exceptions to this base reaction, for example, in some luminous earthworms ${ }^{[\underline{5}]}$ and acorn worms ${ }^{[21]}$, the bioluminescent event is triggered by $\mathrm{H}_{2} \mathrm{O}_{2}$ and not for $\mathrm{O}_{2}$. Besides, the electronic structures, absorption and fluorescence spectra of luciferin, its six analogues and its oxidized form, "oxyluciferin" showed clear evidence of the lack of fluorescence in Latia neritoides [22].

The cellular mechanisms and the genes involved with bioluminescence in dinoflagellates are well characterized. The bioluminescence system in these organisms is unique, from a molecular and cellular point of view. The production of light takes place in specialized organelles, the scintillons, which contain

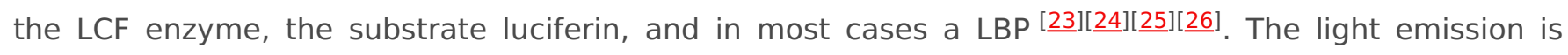
based on LCF-catalyzed oxidation of the luciferin, generally protected from oxidation by LBP that binds the luciferin at physiological $\mathrm{pH}$ (Figure 1). Furthermore, molecular studies have demonstrated a high variation in the sequences of LBP, showing a highly diverse gene family including several non-identical copies arranged in tandem within the genome [ㄱ][28], like in Lingulodinium polyedra [27][29]][30], Noctiluca scintillans [31], Alexandrium spp [32][33][34], and Pyrocystis lunula [35]. The LBP has also been found in the genera Gonyaulax, Ceratocorys, Protoceratium [36][37]. 
Until recently, it was thought that the genus Pyrocystis was among the few ones lacking the presence of the LBP [23][25][그 such as in genera Ceratium, Fragilidium, and Protoperidinium [37]; however, this fact was refuted by the recent detection and characterization of LBP in P. lunula [38]. Emerging information shows substantial evidence that LBP is an integral component of the standard molecular

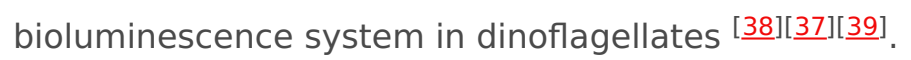

Another important fact that today remains an enigma refers to what is the exact mechanism underlying the luciferin synthesis process. In P. Iunula, in contrast to other bioluminescent dinoflagellates, the levels of LCF and luciferin are constant throughout the daily cycle [25]. Therefore, the rhythm is related to changes in their intracellular localization, instead of daily de novo synthesis and destruction of all the components [ㅌ] $[\underline{40]}$. According to available evidence, it has been proposed that luciferin can be synthesized through different ways, and is thought to be universal in dinoflagellates, because luciferin from any dinoflagellate bioluminescent species can be used as subtract to produce light [41]. It was suggested that luciferin is a photo-oxidation breakdown product of chlorophyll a [42]; however, this would not be true in all cases since $L$. polyedra only contains luciferin during the night period when photooxidation is not possible; and Protoperidinium crassipes can preserve even one year its bioluminescence in the absence of food with chlorophyll or luciferin [43] and, therefore, it can be suggested that it contains luciferin originated from a different precursor. It is likely that more than one mechanism is responsible for luciferin production [44]. In fact, a study with amino acid tracers has confirmed the intracellular production of luciferin, and in this regard, Fresneau and Arrio [44] argue that bioluminescence in dinoflagellates is ruled by the reduction state of the luciferin precursor. Regarding the controversies in relation to these issues, and due to the ecological importance of Dinophyceae in marine environments and to the bioluminescence as a strategy for competition and/or survival, we have made a comprehensive literature review and metanalysis that explores the current available knowledge in relation to the function of bioluminescence in dinoflagellates and the description of the key players involved in the production of bioluminescence. It also gives some new perspectives regarding the phylogenetic diversity/conservation of protein sequence, structure and evolutionary pattern of these key players.

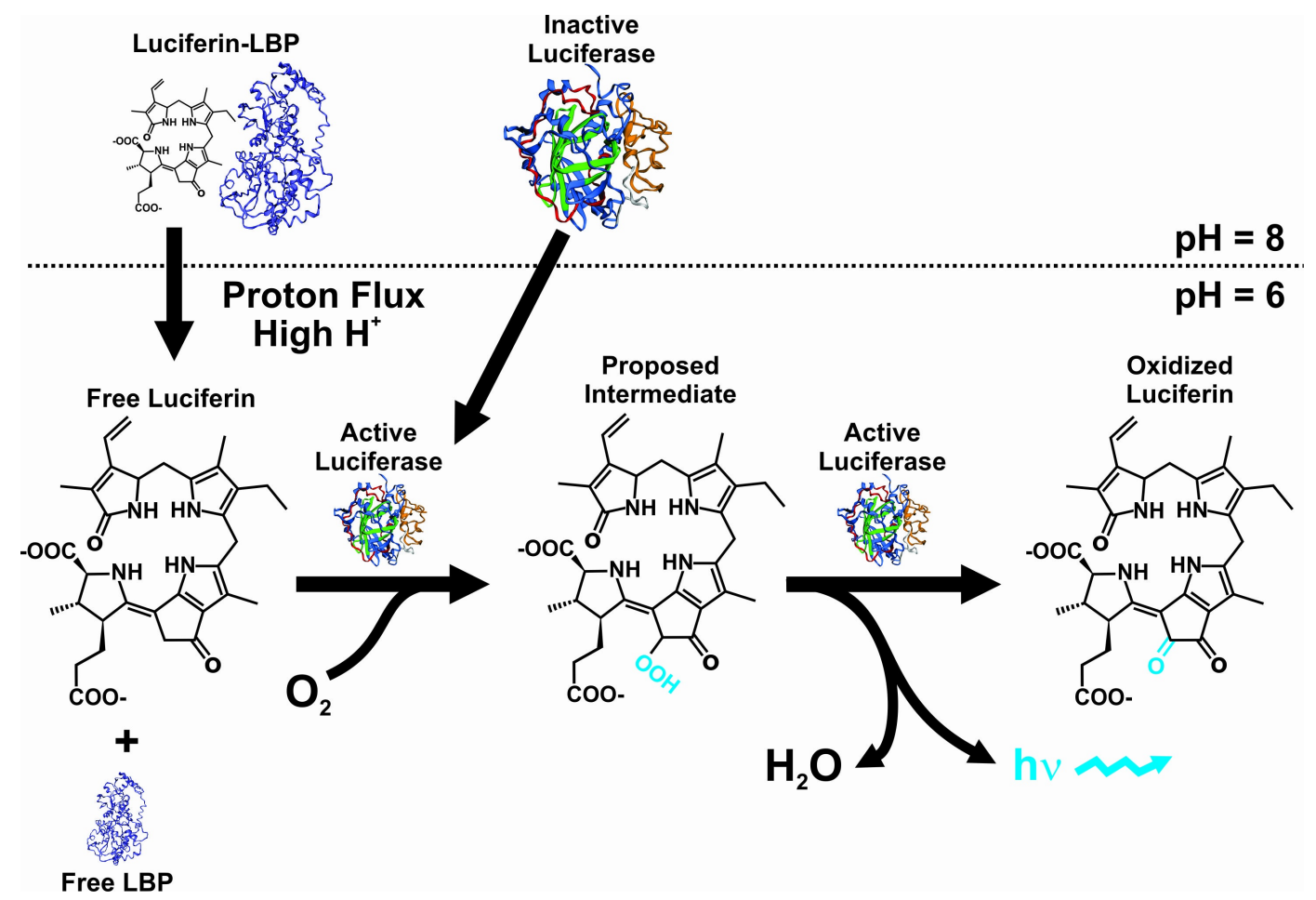

Figure 1. Bioluminescence model in dinoflagellates, showing the efect of $\mathrm{pH}$ on both LBP and LCF. Modified from the proposed model by Rüdiger Hardeland (http://tolweb.org/notes/?note_id=5621) and work published by Morse et al [으].

\section{References}


1. J. D. Andrade; Bioluminescent Marine Phytoplankton Educate. BioScience 1994, 44, 380-381, 10.2307/1312357.

2. Richard H. Backus; Charles S. Yentsch; Asa Wing; Charles S. Yentsch Richard H. Backus; Bioluminescence in the Surface Waters of the Sea. Nature 1961, 192, 518-521, 10.1038/192518a0.

3. C. W. Fuller; P. Kreiss; H. H. Seliger; Particulate Bioluininescence in Dinoflagellates: Dissociation and Partial Reconstitution. Science 1972, 177, 884-885, 10.1126/science.177.4052.884.

4. Liming Li; J. Woodland Hastings; The structure and organization of the luciferase gene in the photosynthetic dinoflagellate Gonyaulax polyedra.. Plant Molecular Biology 1998, 36, 275-284, 10.1023/a:1005941421474.

5. Shimomura, O. Bioluminescence: Chemical Principles and Methods; Revised Edition;World Scientific Publishing Co. Pte. Ltd.: Singapore, 2012; ISBN 978-98-1436-608-3.

6. Elijah Swift; W. Rowland Taylor; BIOLUMINESCENCE AND CHLOROPLAST MOVEMENT IN THE DINOFLAGELLATE PYROCYSTIS LUNULA. Journal of Phycology 1967, 3, 77-81, 10.1111/j.1529-8817.1967.tb04634.x.

7. Biggley,W.H.; Swift, E.; Buchanan, R.J.; Seliger, H.H. Stimulable and spontaneous bioluminescence in the marine dinoflagellates, Pyrodinium bahamense, Gonyaulax polyedra, and Pyrocystis lunula. J. Gen. Physiol. 1969, 54, 96122.

8. Bernard Lécuyer; Bernard Arrio; Chantal Fresneau; Pierre Volfin; Dinoflagellate luciferases: Purification of luciferases from Gonyaulax polyedra, Pyrocystis lunula, and Pyrocystis fusiformis. Archives of Biochemistry and Biophysics 1979, 196, 371-384, 10.1016/0003-9861(79)90288-1.

9. Colepicolo, P.; Roenneberg, T.; Morse, D.; Taylor, W.; Hastings, J. Circadian regulation of bioluminescence in the dinoflagellate Pyrocyctis lunula. J. Phycol. 1993, 29, 173-179.

10. Kirsten Heimann; Paul L. Klerks; Karl Hasenstein; Involvement of actin and microtubules in regulation of bioluminescence and translocation of chloroplasts in the dinoflagellate Pyrocystis lunula. Botanica Marina 2009, 52, , 10.1515/bot.2009.010.

11. Jenny L. Stauber; Monique T. Binet; Vivien W. W. Bao; Jenny Boge; Amy Q. Zhang; Kenneth Mei Yee Leung; Merrin Adams; Comparison of the Qwiklite ${ }^{\mathrm{TM}}$ algal bioluminescence test with marine algal growth rate inhibition bioassays. Environmental Toxicology 2008, 23, 617-625, 10.1002/tox.20400.

12. Zacariah L. Hildenbrand; Alexandra Osorio; Doug D. Carlton; Brian E. Fontenot; Jayme L. Walton; Laura R. Hunt; Hyppolite Oka; Dan Hopkins; Bryan Bjorndal; Kevin A. Schug; Rapid Analysis of Eukaryotic Bioluminescence to Assess Potential Groundwater Contamination Events. Journal of Chemistry 2015, 2015, 1-6, 10.1155/2015/957608.

13. Chun Wu; Takaaki Kurinomaru; Development of the Bioluminescent Immunoassay for the Detection of 5Hydroxymethylcytosine in Dinoflagellate. Analytical Sciences 2019, 35, 301-305, 10.2116/analsci.18p401.

14. Tsvetan R. Bachvaroff; Sebastian G. Gornik; Gregory T. Concepcion; Ross F. Waller; Gregory S. Mendez; J. Casey Lippmeier; Charles F. Delwiche; Dinoflagellate phylogeny revisited: using ribosomal proteins to resolve deep branching dinoflagellate clades.. Molecular Phylogenetics and Evolution 2013, 70, 314-22, 10.1016/j.ympev.2013.10.007.

15. Elijah Swift; Charles C. Remsen; THE CELL WALL OF PYROCYSTIS SPP. (DINOCOCCALES)1,2 Journal of Phycology 1970, 6, 79-86, 10.1111/j.0022-3646.1970.00079.x.

16. Seo, K.; Fritz, L. Cell ultrastructural changes correlate with circadian rhythms in Pyrocystis lunula (Pyrrophyta). J. Phycol. 2000, 36, 351-358.

17. Dinoflagellates. Dinoflagellates 1984, null, , 10.1016/c2009-0-02976-6.

18. Elbrächter, M.; Drebes, G. Life cycles, phylogeny and taxonomy of Dissodinium and Pyrocystis (Dinophyta). Helgol. Mar. Res. 1978, 31, 347-366.

19. Seo, K.; Fritz, L. Evidence for sexual reproduction in the marine dinoflagellates, Pyrocystis noctiluca and Pyrocystis lunula (Dinophyta). J. Phycol. 2001, 37, 530-535.

20. Hastings, J.W. Circadian rhythms in dinoflagellates: What is the purpose of synthesis and destruction of proteins? Microorganisms 2013, 1, 26-32.

21. Shanks, A. An Identification Guide to the Larval Marine Invertebrates of the Pacific Northwest; Oregon State University Press: Corvalis, OR, USA, 2001; pp. 291-293.

22. Mohan Yu; Yoshihiro Ohmiya; Panče Naumov; Ya-Jun Liu; Theoretical Insight into the Emission Properties of the Luciferin and Oxyluciferin of Latia. Photochemistry and Photobiology 2018, 94, 540-544, 10.1111/php.12876.

23. Ruth E. Schmitter; David Njus; Frank M. Sulzman; Van D. Gooch; J. W. Hastings; Dinoflagellate bioluminescence: A comparative study of invitro components. Journal of Cellular Physiology 1976, 87, 123-134, 10.1002/jcp.1040870115.

24. C. H. Johnson; S Inoue; A Flint; J W Hastings; Compartmentalization of algal bioluminescence: autofluorescence of bioluminescent particles in the dinoflagellate Gonyaulax as studied with image-intensified video microscopy and flow cytometry.. The Journal of Cell Biology 1985, 100, 1435-1446, 10.1083/jcb.100.5.1435.

25. Knaust, R.; Urbig, T.; Li, L.; Taylor, W.; Hastings, J. The circadian rhythm of bioluminescence in Pyrocystis is not due to diferences in the amount of luciferase: A comparative study of three bioluminescent marine dinoflagellates. J. Phycol. 1998, 34, 167-172. 
26. Hidetoshi Akimoto; Chun Wu; Tomoya Kinumi; Yoshihiro Ohmiya; Biological rhythmicity in expressed proteins of the marine dinoflagellate Lingulodinium polyedrum demonstrated by chronological proteomics. Biochemical and Biophysical Research Communications 2004, 315, 306-312, 10.1016/j.bbrc.2004.01.054.

27. S Machabée; L Wall; D Morse; Expression and genomic organization of a dinoflagellate gene family. Plant Molecular Biology 1994, 25, , null.

28. Naomi Tanikawa; Hidetoshi Akimoto; Katsunori Ogoh; Wu Chun; Yoshihiro Ohmiya; Expressed Sequence Tag Analysis of the Dinoflagellate Lingulodinium polyedrum During Dark Phaseף. Photochemistry and Photobiology 2004, 80, 31, 10.1562/2004-03-12-ra-110.1.

29. Margaret Fogel; J.Woodland Hastings; A substrate-binding protein in the Gonyaulax bioluminescence reaction. Archives of Biochemistry and Biophysics 1971, 142, 310-321, 10.1016/0003-9861(71)90289-x.

30. D Morse; A M Pappenheimer; J W Hastings; Role of a luciferin-binding protein in the circadian bioluminescent reaction of Gonyaulax polyedra.. Journal of Biological Chemistry 1989, 264, , null.

31. Liu, L.; Hastings, J. Two diferent domains of the luciferase gene in the heterotrophic dinoflagellate Noctiluca scintillans occur as two separate genes in photosynthetic species. Proc. Natl. Acad. Sci. USA 2007, 104, 696-701.

32. Deana Erdner; Donald M. Anderson; Global transcriptional profiling of the toxic dinoflagellate Alexandrium fundyense using Massively Parallel Signature Sequencing. BMC Genomics 2006, 7, 88-88, 10.1186/1471-2164-7-88.

33. Uribe, P.; Fuentes, D.; Valdés, J.; Shmaryahu, A.; Zúñiga, A.; Holmes, D.; Valenzuela, P. Preparation and analysis of an expressed sequence tag library fromthe toxic dinoflagellate Alexandrium catenella. Mar. Biotechnol. 2008, 10, $692-700$.

34. Nina Jaeckisch; Ines Yang; Sylke Wohlrab; Gernot Glöckner; Juergen Kroymann; Heiko Vogel; Allan Cembella; Uwe John; Comparative Genomic and Transcriptomic Characterization of the Toxigenic Marine Dinoflagellate Alexandrium ostenfeldii. PLOS ONE 2011, 6, e28012, 10.1371/journal.pone.0028012.

35. Carlos Fajardo; Francisco Amil-Ruiz; Carlos Fuentes Almagro; Marcos De Donato; Gonzalo Martinez-Rodriguez; Almudena Escobar Niño; Rafael Carrasco; Juan Miguel Mancera; Francisco Fernandez-Acero; An omic approach to Pyrocystis lunula: New insights related with this bioluminescent dinoflagellate.. Journal of Proteomics 2019, 209, 103502, 10.1016/j.jprot.2019.103502.

36. Jeremiah D Hackett; Todd E. Scheetz; Hwan Su Yoon; Marcelo Bento Soares; Maria F Bonaldo; Thomas L. Casavant; Debashish Bhattacharya; Insights into a dinoflagellate genome through expressed sequence tag analysis. BMC Genomics 2005, 6, 80-80, 10.1186/1471-2164-6-80.

37. Martha Valiadi; María Débora Iglesias-Rodríguez; Diversity of the Luciferin Binding Protein Gene in Bioluminescent Dinoflagellates - Insights from a New Gene in Noctiluca scintillans and Sequences from Gonyaulacoid Genera. Journal of Eukaryotic Microbiology 2013, 61, 134-145, 10.1111/jeu.12091.

38. Valiadi, M.; Iglesias-Rodriguez, M. Understanding bioluminescence in dinoflagellates: How far have we come? Microorganisms 2013, 1, 3-25.

39. Okamoto, O.; Liu, L.; Robertson, D.; Hastings, J. Members of a dinoflagellate luciferase gene family difer in synonymous substitution rates. Biochemistry 2001, 40, 15862-15868.

40. Hideshi Nakamura; Yoshito Kishi; Osamu Shimomura; David Morse; J. Woodland Hastings; Structure of dinoflagellate luciferin and its enzymic and nonenzymic air-oxidation products. Journal of the American Chemical Society 1989, 111, 7607-7611, 10.1021/ja00201a050.

41. George Topalov; Yoshito Kishi; Chlorophyll Catabolism Leading to the Skeleton of Dinoflagellate and Krill Luciferins: Hypothesis and Model Studies. Angewandte Chemie International Edition 2001, 40, 3892-3894, 10.1002/15213773(20011015)40:20<3892::aid-anie3892>3.0.co;2-h.

42. Aika Yamaguchi; Takeo Horiguchi; CULTURE OF THE HETEROTROPHIC DINOFLAGELLATEPROTOPERIDINIUM CRASSIPES(DINOPHYCEAE) WITH NONCELLULAR FOOD ITEMS1. Journal of Phycology 2008, 44, 1090-1092, 10.1111/j.1529-8817.2008.00547.x.

43. Chun Wu; Hidetoshi Akimoto; Yoshihiro Ohmiya; Tracer studies on dinoflagellate luciferin with [15N]-glycine and [15N]-I-glutamic acid in the dinoflagellate Pyrocystis lunula. Tetrahedron Letters 2003, 44, 1263-1266, 10.1016/s0040-4039(02)02815-0.

44. C. Fresneau; B. Arrio; Pyrocystis lunula bioluminescence: Physicochemical characterization of the luciferin precursor. Archives of Biochemistry and Biophysics 1988, 265, 22-27, 10.1016/0003-9861(88)90366-9.

\section{Keywords}

luciferase; luciferin-binding protein; luciferin; P630; blue compound; glutathione S-transferase

(c) 2020 by the author(s). Distribute under a Creative Commans CC BY license 